\title{
EVALUASI KEPUASAN PENGGUNA LULUSAN TERHADAP LULUSAN PROGRAM STUDI DIPLOMA III REKAM MEDIK DAN INFORMASI KESEHATAN (RMIK)
}

\author{
Dyan Angesti., S.Kom., MM \\ STIKES Yayasan Rumah Sakit Dr. Soetomo, Jl. Karangmenjangan 12 Surabaya 60286 \\ Surel:ㅁyanangesti@gmail.com
}

\begin{abstract}
ABSTRAK
Peranan stake holder tidak mungkin dapat dikesampingkan, karena merekalah pihak pengguna lulusan dari STIKES Yayasan Rumah Sakit Dr. Soetomo khususnya program studi RMIK. Kebutuhan dan penilaian stake holder dapat dipergunakan sebagai bahan evaluasi oleh STIKES dalam memperbaiki kualitas lulusan, memastikan bahwa lulusan telah memiliki kemampuan dan keahlian sesuai dengan kebutuhan pengguna lulusan serta digunakan sebagai umpan balik dalam rangka meningkatkan mutu lulusan secara keseluruhan. Jenis penelitian adalah penelitian deskriptif, dengan menggunakan variabel Integritas, Profesionalisme, Kepribadian, Kemampuan berkomunikasi, Leadership, Penguasaan tehnologi, Kerjasama tim dan Pengendalian diri. Populasi dalam penelitian ini adalah 27 instansi pelayanan kesehatan pengguna lulusan di kota Surabaya. Waktu pelaksanaan adalah bulan JuliSeptember 2013. Instrumen penelitian menggunakan lembar kuesioner. Hasil dari penelitian adalah pelanggan merasa puas terhadap integritas, Profesionalisme, Kepribadian, Kemampuan berkomunikasi, Leadership, Penguasaan tehnologi, Kerjasama tim dan Pengendalian diri dari alumni STIKES yayasan RS. Dr. Soetomo. Kepuasan pelanggan tertinggi terletak pada variable kepribadian lulusan, sedangkan tingkat kepuasan terendah terletak pada variable cara komunikasi lulusan STIKES yayasan RS. Dr. Soetomo.
\end{abstract}

Kata Kunci: Evaluasi kepuasan, Pengguna Lulusan

\section{USER SATISFACTION EVALUATION OF GRADUATES ON VOCATIONAL PROGRAM MAJORING MEDICAL RECORD AND HEALTH INFORMATION}

\begin{abstract}
The role of stakeholders may not be excluded, because they were user of the graduates STIKES Yayasan Rumah Sakit Dr. Soetomo especially RMIK study program. Need and assessment of stakeholder could be used as an evaluation by STIKES to improving the quality of graduates, ensuring that graduates had the ability and expertise in accordance with need of user graduates and used as feedback in order to improve the overall quality of graduates. This was an descriptive study, using variable Integrity, Professionalism, personality, ability to communicate, Leadership, Control technology, team work and self-control. The population in this study were 27 graduates user health care institutions in Surabaya. This research was conducted from July to September 2013. The research instrument used questionnaire. The results showed that customers were satisfied with the integrity, professionalism, personality, ability to communicate, Leadership, Control technology, team work and self-control of the alumni STIKES Yayasan RS. Dr Soetomo. Highest customer satisfaction was the personality graduates, while the way communication graduates as the lowest level of customer satisfaction.
\end{abstract}

Keyword : Evaluation of satisfaction, user graduates 
Pemasaran adalah suatu proses sosial dan manajerial dimana individu dan kelompok mendapatkan kebutuhan dan keinginan mereka dengan menciptakan, menawarkan dan bertukar sesuatu yang bernilai satu sama lain. Proses pemasaran terdiri dari analisa peluang pasar, meneliti dan memilih pasar sasaran, merancang strategi pemasaran, merancang program pemasaran, dan mengorganisir, melaksanakan serta mengawasi usaha pemasaran.Kepuasan pelanggan adalah suatu keadaan dimana keinginan, harapan dan keperluan pelanggan dipenuhi. Suatu pelayanan dinilai memuaskan bila ia dapat memenuhi kebutuhan dan harapan pelanggannya. Ada beberapa faktor yang dapat dipertimbangkan oleh pelanggan dalam menilai suatu pelayanan, yaitu: ketepatan waktu, dapat dipercaya, kemampuan teknis, diharapkan, berkualitas dan harga yang sepadan.

Berdasarkan faktor-faktor tersebut, pelanggan sendiri yang menilai tingkat kepuasan yang mereka terima dari barang atau jasa spesifik yang diberikan, serta tingkat kepercayaan mereka terhadap kemampuan pemberi pelayanan. Tingkat kepuasan pelanggan terhadap pelayanan merupakan faktor yang penting dalam mengembangkan suatu sistim penyediaan pelayanan yang tanggap terhadap kebutuhan pelanggan, meminimalkan biaya dan waktu serta memaksimalkan dampak pelayanan terhadap populasi sasaran.

Sejalan dengan hal tersebut diatas, Sekolah Tinggi Ilmu Kesehatan (STIKES) Yayasan Rumah Sakit. Dr. Soetomo (YRSDS) sebagai salah satu lembaga pendidikan dibidang kesehatan yang memiliki visi untuk menghasilkan lulusan yang secara mandiri maupun bersama kelompok lain mampu bekerja secara profesional untuk mengembangkan sistem informasi medis dan informasi manajemen rumah sakit/unit pelayanan kesehatan melalui pendekatan teknologi informasi yang canggih. Lulusan dari STIKES YRSDS Program Studi Rekam Medik Informasi Kesehatan (RMIK) mendapatkan gelar Ahli Madya Perekam Kesehatan (Amd, P.K) dan mereka telah mendapatkan bekal untuk profesi perekam medis yang terangkum didalam satuan kurikulum pembelajaran sesuai dengan kompetensi perekam medis.Keberadaan perekam medis diperkuat dengan dikeluarkannya Peraturan Menteri Kesehatan Republik Indonesia nomer 269/MENKES/PER/III/2008.

Apa yang telah dicapai saat ini bukan sekedar prestasi bagiSTIKES YRSDS, namun juga dapat sebagai signal untuk mewaspadai kualitas lulusannya. Apabila terjadi ketimpangan antara kebutuhan dari pengguna dengan kemampuan yang dimiliki oleh lulusan, maka akan berdampak negatif untuk kedepannya. Oleh karena itu sangat STIKES YRSDS berkeinginan untuk lebih mengetahui kebutuhan dan keinginan pasar. Adapun pasar yang dimaksud disini adalah pengguna lulusan dari STIKES YRSDS yang tersebar di rumah sakit dan puskesmas di Surabaya dan kota lainnya.

STIKES Yayasan Rumah Sakit Dr. Soetomo adalah perguruan tinggi kesehatan swasta milik yayasan Dr. Soetomo merupakan peningkatan status Akademi Perekam Medis dan Informatika Kesehatan (APIKES) Pena Husada yang mendapat ijin penyelenggaraan pendidikan sejak tahun 2003/2004. Saat ini ada 428 alumni lulusan STIKES Yayasan Rumah sakit Dr. Soetomo yang tersebar di seluruh Jawa Timur dan sebagian di luar Jawa Timur Sebagai lembaga pendidikan tinggi, STIKES yayasan Rumah Sakit Dr. Soetomo selain mempunyai misi untuk mencetak tenaga professional di bidang kesehatan, juga dalam peningkatan kualitas institusi kesehatan baik pemerintah maupun swasta, khususnya di bidang manajemen dan kompetensi tenaga kesehatan. 


\begin{tabular}{|c|c|}
\hline Tahun Angkatan & Jumlah \\
\hline Angkatan 2003 & 72 \\
\hline Angkatan 2004 & 77 \\
\hline Angkatan 2005 & 55 \\
\hline Angkatan 2006 & 37 \\
\hline Angkatan 2007 & 49 \\
\hline Angkatan 2008 & 61 \\
\hline Angkatan 2009 & 71 \\
\hline
\end{tabular}

Dalam rangka meningkatkan relevansi Perguruan Tinggi dengan tuntutan pasar kerja, perkembangan Ilmu, Teknologi dan Seni (IPTEKS), serta keinginan untuk meningkatkan kualitas proses pendidikan. Peningkatan kualitas secara berkelanjutan senantiasa akan dilakukan STIKES Yayasan RS Dr. Soetomo untuk meningkatkan kepuasan stake holder. Salah satu aspek yang dituntut untuk dievaluasi secara berkala adalah umpan balik dari pengguna lulusan. Pada kesempatan kali ini mempergunakan pengguna lulusan yang ada di wilayah kota Surabaya.

Dari latar belakang tersebut, maka tujuan penelitian ini adalah untuk mengetahui tingkat Integritas lulusan dari sudut pandang pengguna lulusan, mengetahui tingkat Kepribadian lulusan dari sudut pandang pengguna lulusan, mengetahui tingkat Kemampuan berkomunikasi lulusan dari sudut pandang pengguna lulusan, mengetahui tingkat Leadership lulusan dari sudut pandang pengguna lulusan, mengetahui tingkat Penguasaan tehnologi lulusan dari sudut pandang pengguna lulusan, mengetahui tingkat Penguasaan tehnologi lulusan dari sudut pandang pengguna lulusan, mengetahui tingkat Kerjasama tim lulusan dari sudut pandang pengguna lulusan dan mengetahui tingkat Pengendalian diri lulusan dari sudut pandang pengguna lulusan.

\section{METODE}

Berdasarkan tujuan dan permasalahan penelitian ini, maka jenis penelitian yang dirancang adalah penelitian deskriptif. Metode penelitian deskriptif digunakan untuk memecahkan atau menjawab permasalahan yang sedang dihadapi pada situasi sekarang. Penelitian ini dilakukan dengan menempuh langkah-langkah pengumpulan data, klasifikasi, pengolahan atau analisis data, membuat kesimpulan dan laporan ( Notoatmodjo, 2005 : 138 ). Penelitian ini dilakukan pada bulan Juli sampai dengan Oktober 2013 di seluruh instansi pelayanan kesehatan pengguna lulusan STIKES di Kota Surabaya. Variabel Penelitian yang digunakan adalah: Integritas, Profesionalisme, Kepribadian, Kemampuan berkomunikasi, Leadership, Penguasaan tehnologi, Kerjasama tim dan Pengendalian diri.

Instrumen penelitian adalah alat bantu yang akan digunakan untuk pengumpulan data penelitian (Notoatmodjo,2005:48). Instrumen yang digunakan dalam penelitian ini adalah lembar kuesioner yang ditujukan kepada pengguna lulusan STIKES Yayasan RS. Dr. Soetomo. Pengambilan data dilakukan dengan penyebaran kuesioner kepada pengguna lulusan program studi DIII Rekam Medis dan Informasi Kesehatan (RMIK) tahun lulusan 2012-2013 sebanyak 89 orang.

Menurut Wijono tingkat kepuasan adalah suatu fungsi dari perbedaan antara penampilan yang dirasakan dengan harapan. Sedangkan menurut Sugito, kepuasan pelanggan adalah suatu keadaan dimana keinginan, harapan dan kebutuhan pelanggan dipenuhi. Suatu pelayanan dinilai memuaskan bila pelayanan tersebut dapat memenuhi kebutuhan dan harapan pelanggan.

Pada penelitian, penampilan dan harapan diasumsikan sebagai kinerjadari lulusan dan kinerja yang diharapkan dari lulusan. Sehingga terdapat tiga tingkatkepuasan pasien, yaitu pertama, bila kinerja dari lulusan melebihi harapan pengguna, maka pengguna sangat puas. Kedua, bila kinerja dari lulusan sebanding dengan harapan pengguna, maka pengguna puas. Ketiga, apabila kinerja dari lulusan kurang dari harapan pengguna, maka pengguna tidak puas.

\section{HASIL DAN PEMBAHASAN}

Populasi dalam penelitian ini adalah 27 instansi pelayanan kesehatan pengguna lulusan di kota Surabaya. 
Berdasarkan jenis instansi alumni saat ini terbagi menjadi tiga kategori yaitu: Instansi negeri, Instansi swasta dan Wiraswasta.

Tabel 4.1.

Status tempat kerja alumni

STIKES Yayasan Rumah Sakit Dr. Soetomo

\begin{tabular}{|l|c|c|}
\hline JENIS INSTANSI & JUMLAH & \% \\
\hline Instansi negeri & 60 & $67 \%$ \\
\hline Instansi swasta & 29 & $33 \%$ \\
\hline Wiraswasta & 0 & 0 \\
\hline \multicolumn{1}{|c|}{ TOTAL } & $\mathbf{8 9}$ & $\mathbf{1 0 0 \%}$ \\
\hline
\end{tabular}

Sumber: Data primer, 2013

Dari tabel 1 diatas menunjukkan bahwa jenis instansi tempat kerja alumni saat ini sebanyak 60 orang dari 89 orang $(67 \%)$ bekerja di instansi negeri, 29 orang dari 89 orang (33\%) bekerja di Instansi swasta dan tidak ada satupun yang memilih menjadi wiraswasta $(0 \%)$.

Berikut ini adalah penilaian pengguna lulusan akan Integritas, Profesionalisme, Kepribadian, Kemampuan berkomunikasi, Leadership, Penguasaan tehnologi, Kerjasama tim dan Pengendalian diri dari alumni STIKES YRSDS. Penilaian pengguna lulusan secara keseluruhan dibagi menjadi lima kategori yaitu: sangat baik, baik, sedang, kurang dan tidak ada pendapat.

\section{Integritas lulusan dari sudut pandang pengguna lulusan}

Penilaian pengguna lulusan akan Integritas lulusan yaitu:

Tabel 4.2.

Integritas lulusan

STIKES Yayasan Rumah Sakit Dr.

Soetomo

\begin{tabular}{|l|l|l|}
\hline Integritas & Jumlah & \% \\
\hline Sangat baik & 8 & $8.99 \%$ \\
Baik & 75 & $84.27 \%$ \\
Sedang & 5 & $5.62 \%$ \\
$\begin{array}{l}\text { Kurang } \\
\text { Tidak ada } \\
\text { pendapat }\end{array}$ & 1 & $1.12 \%$ \\
\hline TOTAL & 0 & $0.00 \%$ \\
\hline
\end{tabular}

Sumber: Data primer, 2013

Dari tabel 4.2 diatas menunjukkan bahwa penilaian pengguna lulusan akan Integritas lulusan saat ini sebanyak 8 orang dari 89 orang $(8,99 \%)$ dengan kategori sangat baik, 75 orang dari 89 orang $(84,27 \%)$ dengan kategori baik, 5 orang dari 89 orang $(5,62 \%)$ dengan kategori sedang dan 1 orang $(1,12 \%)$ dengan kategori kurang.

\section{Profesionalisme lulusan dari sudut pandang pengguna lulusan}

Penilaian pengguna lulusan akan Integritas lulusan berdasarkan kategori profesionalisme lulusan yaitu:

Tabel 4.3.

Integritas Lulusan Berdasarkan Kategori

Profesionalisme Lulusan

STIKES Yayasan Rumah Sakit Dr.

Soetomo

\begin{tabular}{|l|l|l|}
\hline Profesionalisme & Jumlah & \% \\
\hline Sangat baik & 6 & $6.74 \%$ \\
Baik & 73 & $82.02 \%$ \\
Sedang & 6 & $6.74 \%$ \\
Kurang & 1 & $1.12 \%$ \\
Tidak ada pendapat & 3 & $3.37 \%$ \\
\hline TOTAL & $\mathbf{8 9}$ & $\mathbf{1 0 0 . 0 0 \%}$ \\
\hline
\end{tabular}

Sumber: Data primer, 2013

Dari tabel 4.3 diatas menunjukkan bahwa penilaian pengguna lulusan akan profesionalisme lulusan saat ini sebanyak 6 orang dari 89 orang $(6,74 \%)$ dengan kategori sangat baik, 73 orang dari 89 orang $(82,02 \%)$ dengan kategori baik, 6 orang dari 89 orang $(6,74 \%)$ dengan kategori sedang, 1 orang dari 89 orang $(1,12 \%)$ dengan tidak memberi pendapat sebanyak 3 orang dari 89 orang $(3,37 \%)$. 


\section{Kepribadian lulusan dari sudut pandang pengguna lulusan}

Penilaian pengguna lulusan akan Integritas lulusan berdasarkan kategori kepribadian lulusan yaitu:

Tabel 4.4.

Integritas Lulusan Berdasarkan Kategori Kepribadian Lulusan

STIKES Yayasan Rumah Sakit Dr.

Soetomo

\begin{tabular}{|l|l|l|}
\hline Kepribadian & Jumlah & \% \\
\hline Sangat baik & 5 & $5.62 \%$ \\
Baik & 77 & $86.52 \%$ \\
Sedang & 5 & $5.62 \%$ \\
Kurang & 0 & $0.00 \%$ \\
Tidak ada pendapat & 2 & $2.25 \%$ \\
\hline TOTAL & $\mathbf{8 9}$ & $\mathbf{1 0 0 . 0 0 \%}$ \\
\hline
\end{tabular}

Sumber: Data primer, 2013

Dari tabel 4.4 diatas menunjukkan bahwa penilaian pengguna lulusan akan Integritas lulusan saat ini sebanyak 5 orang dari 89 orang $(5,62 \%)$ dengan kategori sangat baik, 77 orang dari 89 orang $(86,52 \%)$ dengan kategori baik, 5 orang dari 89 orang $(5,62 \%)$ dengan kategori sedang dan 2 orang $(2,25 \%)$ tidak memberi pendapat.

\section{Komunikasi lulusan dari sudut pandang} pengguna lulusan

Penilaian pengguna lulusan akan Integritas lulusan berdasarkan kategori komunikasi lulusan yaitu:
Tabel 4.5.

Integritas lulusan Berdasarkan Kategori Komunikasi Lulusan

STIKES Yayasan Rumah Sakit Dr.

Soetomo

\begin{tabular}{|l|l|l|}
\hline Komunikasi & Jumlah & \% \\
\hline Sangat baik & 1 & $1.12 \%$ \\
Baik & 61 & $68.54 \%$ \\
Sedang & 20 & $22.47 \%$ \\
Kurang & 5 & $5.62 \%$ \\
Tidak \\
pendapat & & \\
\hline TOTAL & 2 & $2.25 \%$ \\
\hline
\end{tabular}

Sumber: Data primer, 2013

Dari tabel 4.5 diatas menunjukkan bahwa penilaian pengguna lulusan akan Integritas lulusan saat ini sebanyak 1 orang dari 89 orang $(1,12 \%)$ dengan kategori sangat baik, 61 orang dari 89 orang $(68,54 \%)$ dengan kategori baik, 20 orang dari 89 orang $(22,47 \%)$ dengan kategori sedang, 5 orang $(5,62 \%)$ dengan kategori kurang dan 2 orang $(2,25 \%)$ tidak memberi pendapat.

\section{Leadership lulusan dari sudut pandang} pengguna lulusan

Penilaian pengguna lulusan akan Integritas lulusan Berdasarkan Kategori Leadership Lulusan yaitu:

Tabel 4.6.

Integritas lulusan Berdasarkan Kategori

Leadership Lulusan

STIKES Yayasan Rumah Sakit Dr.

Soetomo

\begin{tabular}{|l|l|l|}
\hline Leadership & Jumlah & \% \\
\hline Sangat baik & 3 & $3.37 \%$ \\
Baik & 62 & $69.66 \%$ \\
Sedang & 15 & $16.85 \%$ \\
Kurang & 1 & $1.12 \%$ \\
Tidak ada pendapat & 8 & $8.99 \%$ \\
\hline TOTAL & $\mathbf{8 9}$ & $\mathbf{1 0 0 . 0 0 \%}$ \\
\hline
\end{tabular}


Sumber: Data primer, 2013

Dari tabel 4.6 diatas menunjukkan bahwa penilaian pengguna lulusan akan leadership lulusan saat ini sebanyak 3 orang dari 89 orang $(3,37 \%)$ dengan kategori sangat baik, 62 orang dari 89 orang $(69,66 \%)$ dengan kategori baik, 15 orang dari 89 orang $(16,85 \%)$ dengan kategori sedang, 1 orang $(1,12 \%)$ dengan kategori kurang dan 8 orang $(8,89 \%)$ tidak memberikan pendapat.

\section{Penguasaan IT lulusan dari sudut pandang pengguna lulusan}

Penilaian pengguna lulusan akan Integritas lulusan berdasarkan kategori penguasaan it lulusan yaitu:

Tabel 4.7.

Integritas lulusan Berdasarkan Kategori

Penguasaan IT Lulusan

STIKES Yayasan Rumah Sakit Dr.

Soetomo

\begin{tabular}{|l|l|l|}
\hline Penguasaan IT & Jumlah & \% \\
\hline Sangat baik & 12 & $13.48 \%$ \\
Baik & 70 & $78.65 \%$ \\
Sedang & 6 & $6.74 \%$ \\
Kurang & 0 & $0.00 \%$ \\
Tidak ada pendapat & 1 & $1.12 \%$ \\
\hline TOTAL & $\mathbf{8 9}$ & $\mathbf{1 0 0 . 0 0 \%}$ \\
\hline
\end{tabular}

Sumber: Data primer, 2013

Dari tabel 4.7 diatas menunjukkan bahwa penilaian pengguna lulusan akan Integritas lulusan saat ini sebanyak 12 orang dari 89 orang $(13,48 \%)$ dengan kategori sangat baik, 70 orang dari 89 orang $(78,65 \%)$ dengan kategori baik, 6 orang dari 89 orang $(6,74 \%)$ dengan kategori sedang, dan 1 orang $(1,12 \%)$ tidak memberikan pendapat.

\section{Kerjasama tim lulusan dari sudut pandang pengguna lulusan.}

Penilaian pengguna lulusan akan Integritas lulusan berdasarkan kerjasama tim lulusan yaitu:

Tabel 4.8.

Integritas lulusan Berdasarkan Kerjasama

Tim Lulusan

STIKES Yayasan Rumah Sakit Dr.

Soetomo

\begin{tabular}{|l|l|l|}
\hline Kerjasama Tim & Jumlah & $\%$ \\
\hline Sangat baik & 8 & $8.99 \%$ \\
Baik & 75 & $84.27 \%$ \\
Sedang & 6 & $6.74 \%$ \\
Kurang & 0 & $0.00 \%$ \\
$\begin{array}{l}\text { Tidak } \\
\text { pendapat }\end{array}$ & 0 & $0.00 \%$ \\
\hline TOTAL & $\mathbf{8 9}$ & $\mathbf{1 0 0 . 0 0 \%}$ \\
\hline \multicolumn{2}{|c|}{ Sumber: Data primer, 2013 }
\end{tabular}

Dari tabel 4.8 diatas menunjukkan bahwa penilaian pengguna lulusan akan Integritas lulusan saat ini sebanyak 8 orang dari 89 orang $(8,99 \%)$ dengan kategori sangat baik, 75 orang dari 89 orang $(84,27 \%)$ dengan kategori baik dan 6 orang dari 89 orang $(6,74 \%)$. 


\section{Kerjasama tim lulusan dari sudut pandang pengguna lulusan.}

Penilaian pengguna lulusan akan Integritas lulusan berdasarkan kategori pengendalian diri lulusan yaitu:

Tabel 4.9.

Integritas lulusan Berdasarkan Kategori Pengendalian Diri Lulusan

STIKES Yayasan Rumah Sakit Dr. Soetomo

\begin{tabular}{|l|l|l|}
\hline Pengendalian Diri & Jumlah & \% \\
\hline Sangat baik & 6 & $6.74 \%$ \\
Baik & 74 & $83.15 \%$ \\
Sedang & 7 & $7.87 \%$ \\
Kurang & 0 & $0.00 \%$ \\
Tidak ada pendapat & 2 & $2.25 \%$ \\
\hline TOTAL & $\mathbf{8 9}$ & $\mathbf{1 0 0 . 0 0 \%}$ \\
\hline
\end{tabular}

Sumber: Data primer, 2013

Dari tabel 4.9 diatas menunjukkan bahwa penilaian pengguna lulusan akan Integritas lulusan saat ini sebanyak 6 orang dari 89 orang $(6,74 \%)$ dengan kategori sangat baik, 74 orang dari 89 orang $(83,15 \%)$ dengan kategori baik, 7 orang dari 89 orang $(7,87 \%)$ dengan kategori sedang dan 2 orang $(2,25 \%)$ tidak memberikan pendapat.

Berdasarkan hasil penelitian tersebut menunjukkan bahwa pelanggan merasa puas terhadap pengendalian diri lulusan STIKES Yayasan RS Dr. Soetomo. Hal ini ditunjukkan dari persentase pelanggan yang menyebutkan bahwa pengendalian lulusan STIKES yayasan RS Dr. Soetomo mayoritas dalam kategori baik.

\section{A. Pembahasan}

Peranan stake holder tidak mungkin dapat dikesampingkan, karena merekalah pihak pengguna lulusan dari STIKES Yayasan Rumah Sakit Dr. Soetomo khususnya program studi RMIK. Kebutuhan dan penilaian stake holder dapat dipergunakan sebagai bahan evaluasi oleh STIKES dalam memperbaiki kualitas lulusan, memastikan bahwa lulusan telah memiliki kemampuan dan keahlian sesuai dengan kebutuhan pengguna lulusan serta digunakan sebagai umpan balik dalam rangka meningkatkan mutu lulusan secara keseluruhan.

Berikut ini adalah penilaian pengguna lulusan akan Integritas, Profesionalisme, Kepribadian, Kemampuan berkomunikasi, Leadership, Penguasaan tehnologi, Kerjasama tim dan Pengendalian diri dari alumni STIKES YRSDS. Penilaian pengguna lulusan secara keseluruhan dibagi menjadi lima kategori yaitu: sangat baik, baik, sedang, kurang dan tidak ada pendapat.

\section{Penilaian pengguna lulusan akan Integritas lulusan}

Dari tabel 4.2 diatas menunjukkan bahwa penilaian pengguna lulusan akan Integritas lulusan saat ini sebanyak 8 orang dari 89 orang $(8,99 \%)$ dengan kategori sangat baik, 75 orang dari 89 orang $(84,27 \%)$ dengan kategori baik, 5 orang dari 89 orang $(5,62 \%)$ dengan kategori sedang dan 1 orang $(1,12 \%)$ dengan kategori kurang.

Integritas berasal dari kata latin " Integrated " artinya " komplit ", utuh dan sempurna. Yang berarti tidak ada cacat. Profesionalitas adalah integritas yang teruji, lulusan yang professional adalah lulusan yang memiliki integritas yang teruji, tidak suka menggunakan aji mumpung memanfaatkan kesempatan dalam kesempitan, apalagi kesempatan dalam tanda petik yang selalu bermakna negative. Profesional artinya jika kita bisa menahan diri melakukan penyimpangan seperti itu meskipun kesempatan itu sangat terbuka lebar. Pekerja yang professional tidak akan berani menggunakan kesempatan, apalagi mencuri-curi kesempatan. Integritas yang teruji merupakan modal utama bagi kita untuk menjadi pelayanan masyarakat yang benar-benar berjiwa melayani.

Di masa ini, karakter yang demikian bisa dikatakan satu berbanding seribu, inilah biang kerok kenapa pemerintah kita kurang profesional karena betapa susahnya mencari aparat pemerintah yang benar-benar memiliki integritas yang teruji. Yang banyak adalah aparat pemerintah yang suka 
mencuri-curi kesempatan. Kesempatan sudah ditutup rapat rapat tetapi dasar mentalnya rendah, ada saja celah-celah untuk melakukan penyimpangan. Hal ini bisa terjadi lantaran semua orang suka bermain kongkalikong, atasan dengan bawahan sama- melakukan penyimpangan. Orang memiliki integritas hidup sejalan dengan nilai-nilai prinsipnya. Kesesuaian antara kata-kata dan perbuatan merupakan hal yang esensial.

Berdasarkan hasil penelitian tersebut menunjukkan bahwa pelanggan merasa puas terhadap integritas lulusan STIKES Yayasan RS Dr. Soetomo. Hal ini ditunjukkan dari persentase pelanggan yang menyebutkan bahwa integritas lulusan STIKES Yayasan RS Dr. Soetomo sebagian besar dalam kategori baik.

Tingkat kepuasan adalah suatu fungsi dari perbedaan antara penampilan yang dirasakan dengan harapan. Ada tiga tingkat kepuasan: Bila penampilan kurang dari harapan, pelanggan tidak dipuaskan. Bila penampilan sebanding dengan harapan, pelanggan puas. Apabila penampilan melebihi harapan, pelanggan amat puas atau senang (Wijono, 1999:13).

\section{Penilaian pengguna lulusan akan Integritas lulusan berdasarkan kategori profesionalisme lulusan yaitu:}

Dari tabel 4.3 diatas menunjukkan bahwa penilaian pengguna lulusan akan Integritas lulusan saat ini sebanyak 6 orang dari 89 orang $(6,74 \%)$ dengan kategori sangat baik, 73 orang dari 89 orang $(82,02 \%)$ dengan kategori baik, 6 orang dari 89 orang $(6,74 \%)$ dengan kategori sedang, 1 orang $(1,12 \%)$ dengan kategori kurang dan 3 orang $(3,37 \%)$ tidak memberi pendapat.

Berdasarkan hasil penelitian tersebut menunjukkan bahwa pelanggan merasa puas terhadap tingkat profesionalisme lulusan STIKES yayasan RS Dr. Soetomo. Hal ini ditunjukkan dari persentase pelanggan yang menyebutkan bahwa profesionalisme lulusan STIKES yayasan
RS Dr. Soetomo sebagian besar dalam kategori baik.

Tenaga kesehatan tertentu yang bertugas sebagai pelaksana atau pemberi pelayanan kesehatan diberi wewenang sesuai dengan kompetensi pendidikan yang diperolehnya sehingga terkait erat dengan hak dan kewajibannya. Kompetensi dan kewenangan tersebut menunjukkan kemampuan profesional yang baku dan merupakan standar profesi untuk tenaga kesehatan tersebut. Tenaga kesehatan yang melaksanakan tugas yang sesuai dengan standar profesinya akan mendapatkan perlindungan hukum (Wiyono, 1999 ).

3. Penilaian pengguna lulusan akan Integritas lulusan berdasarkan kategori kepribadian lulusan

Dari tabel 4.4 diatas menunjukkan bahwa penilaian pengguna lulusan akan Integritas lulusan saat ini sebanyak 5 orang dari 89 orang $(5,62 \%)$ dengan kategori sangat baik, 77 orang dari 89 orang $(86,52 \%)$ dengan kategori baik, 5 orang dari 89 orang $(5,62 \%)$ dengan kategori sedang dan 2 orang $(2,25 \%)$ tidak memberi pendapat.

Berdasarkan hasil penelitian tersebut menunjukkan bahwa pelanggan merasa puas terhadap kepribadian yang dimiliki lulusan STIKES Yayasan RS Dr. Soetomo. Hal ini ditunjukkan dari persentase pelanggan yang menyebutkan bahwa kepribadian lulusan STIKES Yayasan RS Dr. Soetomo mayoritas dalam kategori baik.

Manfaat sosial fokus pada hubungan itu sendiri daripada pada hasil transaksi. Para peneliti telah menyimpulkan bahwa manfaat sosial secara positif berhubungan dengan komitmen pelanggan pada hubungan (Goodwin, 1997). Menurut Berry (1995) ikatan sosial antara pelanggan dan karyawan membuat pelanggan memiliki tingkat komitmen yang lebih tinggi pada organisasi. Maka dari itu semakin tinggi hubungan sosial antara seorang pelanggan dan karyawan, semakin tinggi komitmen pelanggan pada penyedia jasa.

\section{Penilaian pengguna lulusan akan} Integritas lulusan berdasarkan kategori 


\section{komunikasi lulusan}

Dari tabel 4.5 diatas menunjukkan bahwa penilaian pengguna lulusan akan Integritas lulusan saat ini sebanyak 1 orang dari 89 orang $(1,12 \%)$ dengan kategori sangat baik, 61 orang dari 89 orang $(68,54 \%)$ dengan kategori baik, 20 orang dari 89 orang $(22,47 \%)$ dengan kategori sedang, 5 orang $(5,62 \%)$ dengan kategori kurang dan 2 orang $(2,25 \%)$ tidak memberi pendapat.

Berdasarkan hasil penelitian tersebut menunjukkan bahwa pelanggan merasa puas terhadap cara komunikasi lulusan STIKES yayasan RS Dr. Soetomo. Hal ini ditunjukkan dari persentase pelanggan yang menyebutkan bahwa cara komunikasi lulusan STIKES yayasan RS Dr. Soetomo mayoritas dalam kategori baik.

Menurut Zheithml and Bitner (1996) kepuasan pelanggan dipengaruhi oleh Fitur produk dan jasa. Kepuasan pelanggan terhadap produk atau jasa secara signifikan

dipengaruhi oleh evaluasi pelanggan terhadap fitur atau jasa. Untuk jasa pelayanan publik fitur yang penting meliputi karyawan yang sangat membantu dan sopan dalam berkomunikasi.

Hal positif dari komunikasi lisan (word of mouth) adalah adanya komunikasi informal antar pelanggan mengenai layanan jasa dan barang. Shet, Mittal dan Newman (1999) dalam Hennig-Thurau et. al (2002), komunikasi lisan (word of mouth) mempunyai kekuatan dalam mempengaruhi pengambilan keputusan mengenai pembelian di masa yang akan datang, khususnya pada bisnis jasa yang mempunyai resiko tinggi untuk para pelanggannya. Hasil penelitian Berry (1983), Glynn dan Lehtinen (1995); Gronroos (1990); Morgan dan Hunt (1994) dalam Hennig-Thurau, et. al (2002), menyatakan bahwa adanya peningkatan kesetiaan pelanggan mampu menarik pelanggan baru.

Lebih lanjut, hasil studi menyatakan bahwa adanya komunikasi lisan juga dapat membantu menarik pelanggan baru, dimana komuniksi lisan biasanya berbentuk sesuatu yang menyenamgkan karena pengalaman dan rekomendasi pada orang lain.

5. Penilaian pengguna lulusan akan Integritas lulusan Berdasarkan Kategori Leadership Lulusan

Dari tabel 4.6 diatas menunjukkan bahwa penilaian pengguna lulusan akan Integritas lulusan saat ini sebanyak 3 orang dari 89 orang $(3,37 \%)$ dengan kategori sangat baik, 62 orang dari 89 orang $(69,66 \%)$ dengan kategori baik, 15 orang dari 89 orang $(16,85 \%)$ dengan kategori sedang, 1 orang $(1,12 \%)$ dengan kategori kurang dan 8 orang $(8,89 \%)$ tidak memberikan pendapat.

Berdasarkan hasil penelitian tersebut menunjukkan bahwa pelanggan merasa puas terhadap leadership lulusan STIKES yayasan RS Dr. Soetomo. Hal ini ditunjukkan dari persentase pelanggan yang menyebutkan bahwa leadership lulusan STIKES yayasan RS Dr. Soetomo mayoritas dalam kategori baik.

6. Penilaian pengguna lulusan akan Integritas lulusan berdasarkan kategori penguasaan teknologi informasi lulusan Dari tabel 4.7 diatas menunjukkan bahwa penilaian pengguna lulusan akan Integritas lulusan saat ini sebanyak 12 orang dari 89 orang $(13,48 \%)$ dengan kategori sangat baik, 70 orang dari 89 orang $(78,65 \%)$ dengan kategori baik, 6 orang dari 89 orang $(6,74 \%)$ dengan kategori sedang, dan 1 orang $(1,12 \%)$ tidak memberikan pendapat.

Berdasarkan hasil penelitian tersebut menunjukkan bahwa pelanggan merasa puas terhadap penguasaan IT lulusan STIKES yayasan RS Dr. Soetomo. Hal ini ditunjukkan dari persentase pelanggan yang menyebutkan bahwa Penguasaan IT lulusan STIKES yayasan RS Dr. Soetomo mayoritas dalam kategori baik.

Kepercayaan terhadap penguasaan IT menciptakan manfaat bagi pelanggan yang pada akhirnya meningkatkan komitmen dan loyalitas pelanggan pada hubungan (Morgan dan Hunt 1994). Maka dari itu, manfaat kepercayaan seharusnya berpengaruh secara positif pada komitmen pelanggan. 


\section{Penilaian pengguna lulusan akan Integritas lulusan berdasarkan kerjasama tim}

Dari tabel 4.8 diatas menunjukkan bahwa penilaian pengguna lulusan akan Integritas lulusan saat ini sebanyak 8 orang dari 89 orang $(8,99 \%)$ dengan kategori sangat baik, 75 orang dari 89 orang $(84,27 \%)$ dengan kategori baik dan 6 orang dari 89 orang $(6,74 \%)$.

Berdasarkan hasil penelitian tersebut menunjukkan bahwa pelanggan merasa puas terhadap tingkat kerjasama tim lulusan STIKES yayasan RS Dr. Soetomo. Hal ini ditunjukkan dari persentase pelanggan yang menyebutkan bahwa tingkat kerja sama tim lulusan STIKES yayasan RS Dr. Soetomo mayoritas dalam kategori baik.

Komitmen dan kepercayaan merupakan kunci bagi keberhasilan hubungan karena mendorong pemasar untuk bekerjasama dengan mitra pertukaran dalam menjaga hubungan, menolak manfaat jangka pendek

untuk mendapatkan manfaat jangka panjang, memandang tindakan yang berpotensi memiliki resiko tinggi secara bijaksana dengan keyakinan bahwa mitra mereka tidak akan bertindak secara oportunis. Mereka menyatakan bahwa ketika ada komitmen dan kepercayaan, hasilnya adalah efisiensi, produktivitas dan efektivitas.

8. Penilaian pengguna lulusan akan

\section{Integritas lulusan berdasarkan kategori} pengendalian diri lulusan

Dari tabel 4.9 diatas menunjukkan bahwa penilaian pengguna lulusan akan Integritas lulusan saat ini sebanyak 6 orang dari 89 orang $(6,74 \%)$ dengan kategori sangat baik, 74 orang dari 89 orang $(83,15 \%)$ dengan kategori baik, 7 orang dari 89 orang $(7,87 \%)$ dengan kategori sedang dan 2 orang $(2,25 \%)$ tidak memberikan pendapat. Berdasarkan hasil penelitian tersebut menunjukkan bahwa pelanggan merasa puas terhadap pengendalian diri lulusan STIKES Yayasan RS Dr. Soetomo. Hal ini ditunjukkan dari persentase pelanggan yang menyebutkan bahwa pengendalian lulusan STIKES yayasan RS Dr. Soetomo mayoritas dalam kategori baik.

Pengendalian diri atau Penguasaan diri (Self Regulation) merupakan satu aspek penting dalam kecerdasan emosi (Emotional Quotient). Aspek ini penting sekali dalam kehidupan manusia sebab musuh terbesar manusia bukan berada di luar dirinya, namun justru berada di dalam dirinya sendiri. Pengendalian diri merupakan sikap, tindakan atau perilaku seseorang secara sadar baik direncanakan atau tidak untuk mematuhi nilai dan norma sosial yang berlaku. Mengendalikan diri tidaklah mudah, namun memberikan banyak manfaat.

Untuk mengevaluasi kepuasan terhadap jasa, konsumen umumnya menggunakan atribut (Parasuraman et al., dalam Zeithaml dan Bitner, 2003) yaitu, pertama Reliability (kemampuan untuk melakukan pelayanan yang dijanjikan secara handal dan akurat). Kedua, Responsiveness (keinginan untuk membantu dan memberikan pelayanan yang cepat kepada pelanggan). Ketiga, Assurance yaitu pengetahuan, kemampuan, kesopanan dan sifat dapat dipercaya yang dimiliki karyawan. Keempat, Empathy yaitu perhatian dan pelayanan pribadi yang diberikan kepada pelanggan. Kelima, Tangibles yaitu meliputi fasilitas fisik, perlengkapan, personalia, dan bahan tertulis.

Reaksi yang dapat terjadi apabila pelanggan tidak puas, dari hasil studi di Amerika menunjukan hal-hal berikut yaitu, pertama, $90 \%$ Pelanggan yang tidak puas tidak akan membeli lagi produk; kedua, setiap pelanggan yang tidak puas akan menceritakan kepada paling sedikit 9 orang lain; ketiga, waktu usaha, tenaga dan uang yang diperlukan untuk menarik seseorang pelanggan baru 5 kali lebih banyak daripada untuk mempertahankan seorang pelanggan lama.

Sedangkan apabila pelanggan merasa puas maka setiap pelanggan yang puas akan menceritakannya kepada paling sedikit 5 
orang lainnya, yang sebagian diantaranya dapat menjadi pelanggan.

Kesetiaan pelanggan berpengaruh secara positif pada keuntungan melalui pengurangan biaya dan peningkatan penghasilan per pelanggan (Berry (1995) dalam Hennig-Thurau et. al (2002)). Adanya pelanggan yang setia memberikanpengurangan biaya karena mempertahankan pelanggan membutuhkan lebih sedikit biaya dibanding dengan mencari pelanggan baru. Menurut Dwyer,Schurr dan Oh (1987) dalam Hennig-Thurau et.al(2002), pelanggan yang setia juga memberikan kontribusi dalam meningkatkan penghasilan karena adanya aktivitas penjualan dan rata-rata penetrasi pelanggan yang meningkat.

\section{SIMPULAN}

1. Tingkat Integritas lulusan dari sudut pandang pengguna lulusan

Penilaian pengguna lulusan akan Integritas lulusan dengan kategori baik sejumlah 75 orang dari 89 orang $(84,27 \%)$ merupakan yang tertinggi. Sedangkan terendah 1 orang $(1,12 \%)$ dengan kategori kurang.;

2. Tingkat Kepribadian lulusan dari sudut pandang pengguna lulusan

Penilaian pengguna lulusan akan profesionalisme lulusan dengan kategori baik sejumlah 73 orang dari 89 orang $(82,02 \%)$ merupakan yang tertinggi sedang 1 orang $(1,12 \%)$ dengan kategori kurang merupakan yang terendah;

3. Tingkat Kemampuan berkomunikasi lulusan dari sudut pandang pengguna lulusan

Penilaian pengguna lulusan akan Integritas lulusan dengan kategori baik sejumlah 77 orang dari 89 orang $(86,52 \%)$ merupakan yang tertinggi sedangkan terendah 2 orang $(2,25 \%)$ tidak memberi pendapat.

4. Tingkat leadership lulusan dari sudut pandang pengguna lulusan

Penilaian pengguna lulusan akan Integritas lulusan dengan kategori baik sejumlah 61 orang dari 89 orang $(68,54 \%)$ dengan kategori baik merupakan yang tertinggi sedangkan terendah 2 orang $(2,25 \%)$ tidak memberi pendapat.

5. Tingkat Penguasaan tehnologi lulusan dari sudut pandang pengguna lulusan

Penilaian pengguna lulusan akan Integritas lulusan dengan kategori baik sejumlah 62 orang dari 89 orang $(69,66 \%)$ dengan kategori baik merupakan yang tertinggi sedangkan terendah 1 orang $(1,12 \%)$ dengan kategori kurang;

6. Tingkat Kerjasama tim lulusan dari sudut pandang pengguna lulusan

Penilaian pengguna lulusan akan Integritas lulusan dengan kategori baik sejumlah 75 orang dari 89 orang $(84,27 \%)$ dengan kategori baik sedangkan terendah sedangkan terendah sedangkan terendah sedangkan terendah sedangkan terendah 6 orang dari 89 orang $(6,74 \%)$.

7. Tingkat Pengendalian diri lulusan dari sudut pandang pengguna lulusan.

Penilaian pengguna lulusan akan Integritas lulusan dengan kategori baik sejumlah 74 orang dari 89 orang $(83,15 \%)$ dengan kategori baik sedangkan terendah sejumlah 2 orang $(2,25 \%)$ tidak memberikan pendapat.

\section{BAHAN RUJUKAN}

Berry, Leonard L. (1983) "Relationship Marketing," in Emerging Perspectives on Services Marketing, Leonard L. Berry, G. Lynn Shostack, and Gregory D Upah, eds. Chicago: American Marketing Association, 25-28.

Berry, Leonard L. (1995), “ Relationship Marketing of Services Growing Interest, Emerging Perspectives," Journal of The Acadaemy of Marketing Science 23 (Fall), 236-45

Goodwin, Cahty (1997), "Communality as a Dimensim of Services Relationships," Journal of Consumer Psychology, 5, 387415.

Parasuraman, A Zeithaml,Valerie A dan L Berry. 2003.Reassesment of Expectations asa Comparison Standard in Measuring Service Quality : implication for future research. Journalof Marketing, 58. 
Morgan, Robert M. and Shelby D. Hunt (1994), “ The Commitment-Trust Theory of Relationship Marketing," Journal of Marketing, 58 July, 20-38.

Zeithaml, Valarie A. and Mary Jo Bitner (1996). Services Marketing. New York: McGraw-Hil.

Hennig-Thurau and Alexander Klee (1997). " The Impact of customer Satisfaction and Relationship Quality on Customer Retention - A Critical Reassessment and Mode Development," Psychology and Marketing, 14 (December), 737-65

---, Kevin P. Gwinner, and Dwayne D. Gremler (2000), "Why Customers Build Relationships With Companiesand Why Not," inRelationship Marketing: Gaining Competitive Advantage through Customer Satisfaction and Customer Retention, Thorsten HennigThurau and Ursula Hansen,eds.Berlin,Germany:Springer,369 $-91$.

, Kevin P. Gwinner, and Dwayne D. Gremler (2002), “ Understanding Relationship Marketing Outcome -An Integration of Relational Benefits and Relationship Quality," Journal of Service Research, Volume 4, No.3, February 2002: 230-247

- and Markus Langer, and Ursula Hansen (2001), “ Modeling and Managing Student Loyalty: An Approach Based on The Concept of Relationship Quality," Journal of Service Research, 3 (4), 331-44. 